\title{
'New Normal' in a Hospitality with Family Management in Graha Dewata Juwana Hotel
}

\author{
I Gusti Ketut Indra Pranata Darma* \\ Universitas Hindu Negeri I Gusti Bagus Sugriwa, Denpasar, Indonesia \\ Email: indrapranata@uhnsugriwa.ac.id
}

\begin{abstract}
The hospitality industry is one part of the world of tourism which plays an important role wherever located. The role of the hospitality industry is not only as a place to stop and rest, but it is a beginning of the economic activities of other industries. The arrival of covid-19 virus in early 2020, no doubt hit all the industrial sectors in the world including the hospitality industry. For almost 3 months, people in the world are forced to live in fear of the covid-9 virus. The World Health Organization (WHO) also called for "New Normal" as a new form of adaptation for all people in the world to this virus until a cure is found. Based on the presence of the virus, the hotel industry has welcomed "New Normal" by following strict rules in force following local government recommendations. This research will try to find out the form of the "New Normal" protocol in the hotel industry, especially in the management of family hotels in Juwana, which is one of the areas defined in the red zone. So we get the right steps to be applied to other regions by following the prevailing customs in the area.
\end{abstract}

Keywords: Covid-19; hospitality; New Normal.

\begin{abstract}
Abstrak
Industri perhotelan merupakan salah satu bagian dari dunia Pariwisata yang memegan peranan penting dimanapun berada. Peran industri perhotelan ini tidak hanya sebagai tempat untuk singgah dan beristirahat, melainkan menjadi sebuah awal dari kegiatan perekonomian dari industri lain. Datangnya virus covid-19 di awal tahun 2020, tak pelak memukul segala sektor industri yang ada didunia tidak terkecuali industri perhotelan. Selama hampir 3 bulan, masyarakat di dunia dipaksa untuk hidup berada dalam ketakutan akan virus covid-9. World Health Organization (WHO) pun menyerukan adanya "New Normal" sebagai bentuk adaptasi baru bagi seluruh masyarakat di dunia terhadap virus ini sampai ditemukan obatnya. Berdasarkan adanya virus tersebut, industri pariwisata yang memiliki berbagai macam akomodasi ikut menyambut "New Normal" dengan mengikuti aturan-aturan ketat yang berlaku mengikuti anjuran pemerintah setempat. Pada penelitian ini akan mencoba mengetahui konsistensi penerapan protokol "New Normal" pada industri perhotelan khususnya di pada pengelolaan hotel keluarga di Juwana yang merupakan salah satu daerah yang ditetapkan pada zona merah. Metode penelitian yang digunakan dengan wawancara terpusat kepada pengelola akomdasi, Sehingga didapatkan langkah-langkah dalam menjaga konsistensi dalam menerapkan protokol kesehatan memasuki akomodasi.
\end{abstract}

Kata Kunci: Covid-19; keramahan; New Normal.

\section{A. PENDAHULUAN}

Juwana merupakan daerah pesisir pantai utama pulau jawa yang berbatasan langsung dengan laut jawa. Kota ini merupakan kota kecamatan yang merupakan bagian dari Kabupaten Pati Jawa Tengah dengan potensi pada industri perikanan sebagai mata pencahariaan utama. Kota kecil ini juga dikenal sebagai penghasil beberapa suvenir khas seperti kuningan dan Batik Bakaran Juwana dengan ciri khas tertentu dibandingkan dengan daerah lain.

Padatnya lalu lintas darat maupun lalu lintas bisnis perikanan, ikut mengangkat industri perhotelan sekitar kota Juwana. Hingga virus covid-19 yang menyerang dunia, ikut melumpuhkan hampir semua 
sector industry tidak terkecuali pariwisata. Virus SARSC-CoV-12 atau yang dikenal covid-19 merupakan virus corona yang terdeksi awal di Cina dengan belum diketahui penyebab asal mula terjadinya saat ini (Advisory, 2020). Virus ini menyerang saluran pernafasan manusia, yang pasti mengganggu kehidupan manusia dalam beraktivitas terutamanya pariwisata. Perkembangan yag cepat dari virus ini, membuat banyak kota dan Negara yang mulai memberlakukan kebijakan lockdown di tempatnya (Saadat, Rawtani, \& Hussain, 2020). Penutupan kota dan Negara tersebut tentu menjadi suatu permasalahan tersendiri bagi industry pariwisata.

Organisasi pariwisata dunia memperkirakan terjadi penurunan 20 sampai 30 persen kunjungan wisatawan di seluruh dunia terdampak covid-19 (UNWTO, 2020). Penurunan tersebut tentu menjadi suatu perhatian khusus bagi sector industry yang terdampak adanya covid-19. Meski demikian, masih terdapat optimisme dari para pelaku industry pariwisata khususnya pada bidang perhotelan bahwa pandemic ini hanya akan berlaku selama 4-6 bulan saja (Horwath, 2020). Optimisme tersebut tentu memberikan angin segar dalam tetap menjaga kondisi internal Indonesia. Pengelolaan usaha perhotelan berbasis kekeluargaan memerlukan kecermatan serta modal yang cukup tinggi terutamanya pada masa pandemic dengan segala tantangannya tanpa mengurangi jumlah tenaga kerja yang dimiliki.

Berdasarkan permasalahan tersebut, penulis tertarik untuk mengangkat pengelolaan berbasis keluarga di masa "New Normal" pada industry perhotelan. Pada industry perhotelan yang berbasis keluarga dengan berbagai kendalanya akan memerlukan tindakan serta koordinasi yang tepat dengan pemilik perusahaan.

\section{B. Literatur Review}

\section{New Normal pasca Covid-19}

Istilah "New Normal" merupakan suatu istilah baru yang sebelumnya dikemukakan oleh badan kesehatan dunia (WHO) dalam menyikapi adanya pandemi covid-19 yang diprediksi akan berjalan cukup lama. Covid-19 sendiri merupakan jenis virus baru yang menyerang saluran pernafasan manusia (Yuliana, 2020). Virus ini memiliki kemiripan dengan adanya virus SARS dan MERS yang sebelumnya pernah menyerang manusia (Advisory, 2020). Covid-19 ini tentu akan sangat menggangu kehidupan masyarakat dalam beraktivitas maupun dalam kegiatan pariwisata, sehingga diperlukan sebuah tatanan kehidupan baru yang disebut "New Normal".

Penyebutan kehidupan normal baru (New Normal) merupakan suatu kegiatan adaptasi manusia saat ini terhadap kondisi tertentu (dalam hal ini dengan virus covid-19). Meski demikian tidak menutup kemungkinan bahwa akan terjadi suatu peningkatan kasus baru covid-19 secara signifikan jika tidak menerapkan protocol kesehatan secara tepat (World Health Organization, 2020).

Tatanan kehidupan baru bermula dari adanya virus Covid-19 yang menyebabkan kontak fisik antar manusia menjadi berkurang hingga pembatasan berskala besar dalam bepergian. Adanya pembatasan tersebut telah merubah stabilitas, normalitas serta meningkatkan stress di masyarakat (Bard, 2020).

Kemungkinan untuk kembali pada kehidupan normal yang lama akan sulit terjadi saat ini. Merupakan suatu tantangan dalam kehidupan tatanan baru dalam mengadaptasi segala sektor industri yang ada saat ini(Taylor dalam Ateljevic, 2020). Dua hal tersebut menjadi alasan diterapkannya tatanan kehidupan baru. Kebutuhan manusia akan perekonomian yang baik mendesak pula masyarakat untuk tetap bekerja hingga "New Normal” tersebut diberlakukan. Pada dunia kesehatan pun, kehidupan normal lama yang diharapkan akan memerlukan waktu yang tidak sebentar (Zeegen, Yates, \& Jevsevar, 2020). Kehidupan normal lama yang kita jumpai masih memerlukan waktu yang tidak sebentar dan tatanan 
hidup baru diperlukan sebuah latihan serta kebiasaan untuk mencapainya saat ini. Proses adaptasi tersebut tetap dipercaya merupakan suatu langkah terbaik yang dapat kita jalankan saat ini.

Pada kehidupan tatanan baru, juga membuka peluang baru bagi masyarakat. Tatanan kehidupan baru menjadi inspirasi masyarakat dalam melakukan inovasi kegiatan. Dunia kerja saat ini menjadi lebih fleksibel dalam bekerja meskipun terpisah jarak yang jauh. Seperti dalam pengurusan ijin praktek kerja, surat menyurat, maupun berkas yang sebelumnyaa memerlukan fisik, sekarang menjadi lebih fleksibel penerapannya (Clark, 2020).

Keluwesan dalam berkegiatan juga akan mulai berdampak pada industry perhotelan. Pelayanan secara "flexy-services" akan menjadi suatu alat baru dalam menarik perhatian wisatawan dalam melakukan kunjungan (Ranasinghe et al., 2020). Inovasi baru juga akan ikut berkembang seperti even virtual dan hybrid event mulai akan berkolaborasi dengan industry teknologi. Penyelenggaraa kegiatan MICE juga akan mulai berjalan secara virtual selama penurunan wisatawan hingga virus covid-19 dapat teratasi.

Penurunan wisatawan ini cukup berdampak bagi banyak industry yang bergantung pada pariwisata. Diperlukan campur tangan dari pemerintah setempat dalam menjaga industry pariwisata dengan memberikan relaksasi pajak maupun insentif tertentu dalam menjaga keberlangsungan kehidupan suatu usaha (Kumar, 2020). Kehidupan industry pariwisata dalam "New Normal" akan membutuhkan banyak investasi dalam menjalankan tatanan kehidupan baru tersebut. Mulai penyediaan alat kebersihan lebih, proses pembersihan ruangan hingga sterilisasi terhadap kasus-kasus wisatawan yang mungkin saja terjangkit virus covid-19. Selain itu, penerapan tersebut juga membantu mengedukasi para wisatawan serta meningkatkan kesadaran akan pentingnya penerapan Clean, Health, Safety dan Environment di Industri Pariwisata(Lumanauw, 2020).

\section{Manajemen Keluarga}

Sebuah manajemen keluarga merupakan suatu pengelolaan satu peran yang dapat memberikan peningkatan kualitas hidup terhadap orang lain (Greenhaus \& Powell, 2006). Suatu manajemen keluarga biasanya berdiri dan dikendalikan oleh seorang pemilik tunggal. Pada manajemen keluarga yang tepat, pengelolaan tipe ini biasanya dapat berkembang di tempat yang tersebar untuk mendapatka kinerja yang unggul (López-Delgado \& Diéguez-Soto, 2015). Manajemen berbasis keluarga ini biasanya rawan akan konflik dikarenakan permasalahan seperti masalah internal keluarga hingga nepotisme (Molly, Laveren, \& Deloof, 2010), sehingga dalam mengelola manajemen keluarga akan menjadi suatu tantangan tersendiri.

Pengelolaan berbasis keluarga akan lebih cepat mengalami perubahan setiap generasinya. Salah satu penyebab utamanya adalah kemampuan finansial dari setiap generasi yang berbeda akan berpengaruh pada model pengelolaannya (Darmawan, 2019). Kemampuan finansial dalam suatu perusahaan keluarga yang telah mapan cukup lama juga berpengaruh dalam pengelolaanya. Berbeda dengan pengelolaan perusahaan keluarga yang baru berdiri, yang lebih banyak menggunakan dana internal individu untuk operasionalnya (Coleman \& Carsky, 1999).

Sistem pengelolaan berbasis keluarga sama seperti perusahaan pada umumnya, akan menghadapi berbagai macam dinamika, tantangan, hingga metode persaingan baru dalam dunia global. Perkembangan ini akan selalu terjadi dimulai dari generasi kedua penerus dari manajemen keluarga hingga seterusnya (Galve-Górriz \& Salas-Fumás, 2011). Inovasi yang selalu terkini akan menjadi generasi tersebut dalam mengembangkan bisnis perusahaan tersebut. Banyak inovasi dari suatu perusahaan yang dimulai dari manajemen keluarga, mampu berkembang pesat dan memiliki peran vital dalam perekonomian dunia (Villalonga \& Amit, 2006). Pengelolaan berbasis keluarga tersebut tentu menjadi suatu metode yang patut menjadi perhatian dan tidak dipandang sebelah mata. Seorang manajer perusahaan memerlukan akses 
pemilik dalam komunikasi dan menyelaraskan visi misi dengan para pemegang saham keluarga (Ruan \& Tian, 2011)Akses tersebut merupakan salah satu dampak dari tingginya kekuasaan dari kepemilikan keluarga yang terasa pada tingkat keberpihakan pengambilan keputusan.

Pengelolaan berbasis keluarga memiliki kendali seperti piramida terutamanya di kawasan asia (Claessens, Djankov, \& Lang, 2000). Artinya, pucuk pimpinan dari suatu perusahaan berbasis keluarga akan memiliki kendali penuh dalam menentukan kebijakan. Setiap generasi yang sedang berada pada pucuk pimpinan mengelola akan memiliki peran serta inovasi satu dengan yang lainnya. Keramahan yang akrab dalam pengelolaan berbasis keluarga merupakan salah satu kekuatan yang dimiliki dalam industry perhotelan ini. Dalam kondisi dunia industry yang masih terserang virus covid-19, kemudahan dalam berkomunikasi antara tenaga medis, staff karyawan serta manajemen hotel menjadi salah satu kunci untuk memutus rantai penyebaran covid-19 di industry perhotelan (Hoefer et al., 2020).

\section{Metode Penelitian}

Penelitian ini mengguakan studi kasus di Hotel Graha Dewata Juwana yang terletak di Provinsi Jawa Tengah. Pada penyusunan penelitian kali ini menggunakan subjek seperti pada tabel 1 .

Tabel 1 Subyek Penelitian

\begin{tabular}{lll}
\hline Nama & Pekerjaan & Keterangan \\
\hline Eddy & Pengelola & $\begin{array}{l}\text { Merupakan pengelola hotel yang menangani bagian operasional hotel } \\
\text { baik internal maupun eksternal }\end{array}$ \\
\hline $\begin{array}{l}\text { Arya } \\
\text { Yuanantara }\end{array}$ & $\begin{array}{l}\text { Generasi } \\
\text { kedua } \\
\text { manajemen }\end{array}$ & $\begin{array}{l}\text { Merupakan generasi kedua dalam manajemen keluarga yang } \\
\text { mengelola hotel }\end{array}$ \\
\hline Elly & Karyawan & $\begin{array}{l}\text { Salah satu karyawan yang memiliki masa kerja diatas 2 tahun serta } \\
\text { memiliki pengalaman di akomodasi }\end{array}$ \\
\hline
\end{tabular}

Pada penelitian kali ini, menggunaka wawancara terpusat kepada narasumber yaitu pengelola utama dari akomodasi dan generasi kedua pemilik dari perusahaan. Kriteria yang ditetapkan dalam melakukan wawancara terpusat antara lain:

a) Pengelola industry perhotelan di Juwana sebanyak 1 orang dengan minimal waktu kerja minimal 2 tahun

b) Generasi kedua dari pemilik akomodasi

c) Pegawai akomodasi yang telah bekerja lebih dari 2 tahun

Untuk memperoleh data, akan dilakukan tiga teknik utama yaitu wawancara, observasi dan studi dokumen. Teknik wawancara yang akan ditempuh akan berupa wawancara mendalam terhadap narasumber. Jika masih dirasa kurang, akan ditambah lagi pada narasumber yang kedua.

Observasi yang dilakukan berlokasi di Hotel Graha Dewata Jawa Tengah yang dilakukan secara mandiri. Waktu kegiatan ini dilakukan mulai dari Juli 2020 hingga Januari 2021 pada masa pandemic dengan tetap menerapkan protokol kesehatan sesuai anjuran pemerintah. Kemudian akan dilakukan studi dokumen untuk mengetahui apakah informasi yang didapat ada persamaan dengan teori atau malah 
bisa mendapatkan jenis informasi baru yang berbeda. Untuk deskripsi dari tiap variabel dapat dilihat pada tabel 2.

Tabel 2 Deskripsi Fokus

\begin{tabular}{lll}
\hline No & Variabel & Deskripsi \\
\hline 1 & New Normal & $\begin{array}{l}\text { Merupakan suatu tantangan dalam kehidupan tatanan baru dalam } \\
\text { mengadaptasi segala sektor industri yang ada saat ini(Taylor dalam } \\
\text { Ateljevic, 2020) }\end{array}$ \\
\hline 2 & $\begin{array}{ll}\text { Manajemen } \\
\text { Keluarga }\end{array}$ & $\begin{array}{l}\text { Suatu pengelolaan oleh keluarga yang biasanya berdiri dan dikendalikan } \\
\text { oleh seorang pemilik tunggal. Pada manajemen keluarga yang tepat, } \\
\text { pengelolaan tipe ini biasanya dapat berkembang di tempat yang tersebar } \\
\text { untuk mendapatka kinerja yang unggul (López-Delgado \& Diéguez-Soto, } \\
\text { 2015) }\end{array}$
\end{tabular}

\section{Hasil dan Pembahasan}

\section{New Normal dalam Industri Perhotelan}

Industri Perhotelan yang mengedepankan pelayanan serta keramahan dalam melayani wisatawan, tidak bisa terlepas dari kontak langsung kepada segala macam barang wisatawan. Munculnya virus covid19 menjadi sebuah dilema tersendiri bagi industry perhotelan ini. Pemerintah Indonesia turut memberikan langkah nyata dengan mencetuskan tatanan kehidupan normal baru atau yang disebut "New Normal". Berdasarkan data tabel 3, terdapat penurunan jumlah tamu yang baik dari wisatawan maupun yang melakukan kunjungan bisnis ke hotel selama masa pandemi.

\section{Tabel 3 Jumlah Kunjungan tamu Juli-Desember 2020}

\begin{tabular}{lll}
\hline No & Bulan & Jumlah Tamu \\
\hline 1 & Juli & 368 \\
\hline 2 & Agustus & 336 \\
\hline 3 & September & 310 \\
\hline 4 & Oktober & 375 \\
\hline 5 & November & 320 \\
\hline 6 & Desember & 300 \\
\hline
\end{tabular}

Industri perhotelan mengadaptasi tatanan kehidupan baru ini dengan lebih fleksibel. Fleksibilitas dapat diterapkan dengan mengurangi kontak langsung dalam kegiatan fisik seperti surat menyurat (Clark, 2020). Fleksibilitas menjadi suatu kunci dalam tetap mengurangi penyebaran covid-19.

Beberapa tatanan kehidupan baru yang dapat diterapkan pada industry perhotelan antara lain (PHRI, 2020):

a) Memeriksa suhu tubuh karyawan yang diatas 37,3 derajat Celcius.

b) Penerapan gaya hidup bersih karyawan dengan rajin mencuci tangan sebelum, selama dan sesudah bekerja.

c) Penggunaan masker saat akan menuju lokasi hotel, dan mengganti masker saat akan memulai bekerja di hotel.

d) Penyediaan hand sanitizer pada lokasi yang dianggap perlu oleh pihak hotel. 
e) Menghindari kerumunan

f) Mengurangi kontak fisik dalam melakukan registrasi tamu

Penerapan protocol baru tersebut di dalam hotel, diperlukan suatu kebiasaan dalam jangka waktu tertentu. Pada Hotel Graha Dewata, penerapan protokol kesehatan masih bersifat fleksibel disesuaikan dengan kondisi dan situasi. Arya pengelola hotel Graha Dewata mengungkapkan penerapan protokol akan semakin ketat bila menghadapi kerumunan seperti adanya acara pernikahan atau rombongan tentu dengan arahan dari pihak terkait sebelumnya.

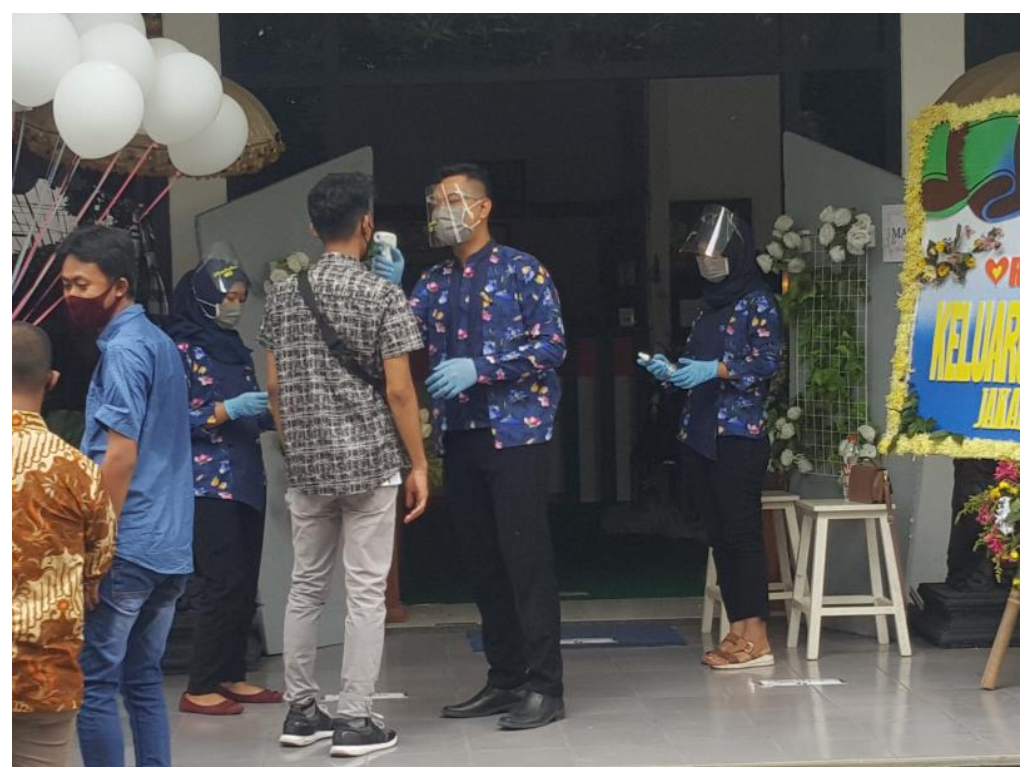

Gambar 1 Konsistensi penerapan protokol saat ada event

Pada pelaksanaanya, sering dijumpai beberapa tamu yang tetap berkerumun setelah memasuki ruang acara sehingga cukup merisaukan bagi pengelola. Menurut arya, tindakan yang dapat dilakukan pada kondisi tersebut hanya himbauan untuk segera meninggalkan tempat acara. Terlihat pada gambar 1, antrian tamu yang akan menghadiri acara pernikahan meskipun sudah dilakukan pembatasan jumlah undangan. Protokol pemeriksaan juga ditigkatkan dengan menambah personil acara. Proses edukasi serta pemberian informasi kepada tamu secara terus menerus dilakukan dengan harapan dapat memberikan rasa aman dan nyaman kepada tamu yang berkunjung ada era tatanan kehidupan baru saat ini (Fajri, 2020).

Pada kunjungan awal di akomodasi penginapan yang telah dilakukan, ada beberapa hal yang menjadi sorotan diantaranya:

a) Keseragaman dalam melakukan pemeriksaan di setiap tamu berbeda-beda dalam artian belum konsisten antara tamu satu dengan yang lain dalam pengecekan suhu.

b) Masih terbatasnya himbauan-himbauan secara tertulis di akomodasi dalam mengingatkan tamu mengenai kepatuhan akan protokol kesehatan.

Menurut Eddy selaku pengelola yang berhubungan langsung dengan tamu, salah satu kendala dalam konsistensi pemeriksaan protokol adalah adanya 3 akses masuk yang memungkinkan keterbatasan dalam pegawasan. Faktor lain adalah pengurangan jam tenaga kerja yang berimbas pada pengawasan tamu yang dalam kasus tertentu mengalami ketidakseimbangan. Pada lokasi di Hotel Graha Dewata, idealnya 1 orang tenaga kerja mampu melakukan pemantauan hingga 5 orang. Pada bulan Oktober 2020 yang bertepatan dengan libur panjang, terjadi peningkatan kunjungan wisatawan hingga 80 persen 
sehingga cukup mengalami kesulitan saat mengatasi kunjungan wisatawan. Menurut Eddy, pada waktu tersebutlah masa yang diperketat dalam melakukan protokol kesehatan mulai pemeriksaan suhu serta kebiasaan cuci tangan sebelum masuk lobby hotel.

Pengelolaan yang berbasis kekeluargaan nyatanya belum mampu dalam menekan angka penyebaran covid-19 seperti yang disampaikan sebelumnya. Namun pengelolaan berbasis keluarga secara efektif mampu meningkatkan kemampuan serta keluwesan komunikasi antar departemen maupun antar karyawan (Hoefer et al., 2020). Terlihat koordinasi yang terjalin saat mendapati kerumunan kegiatan pernikahan dan dengan segera mampu diantisipasi terlihat pada gambar 2.

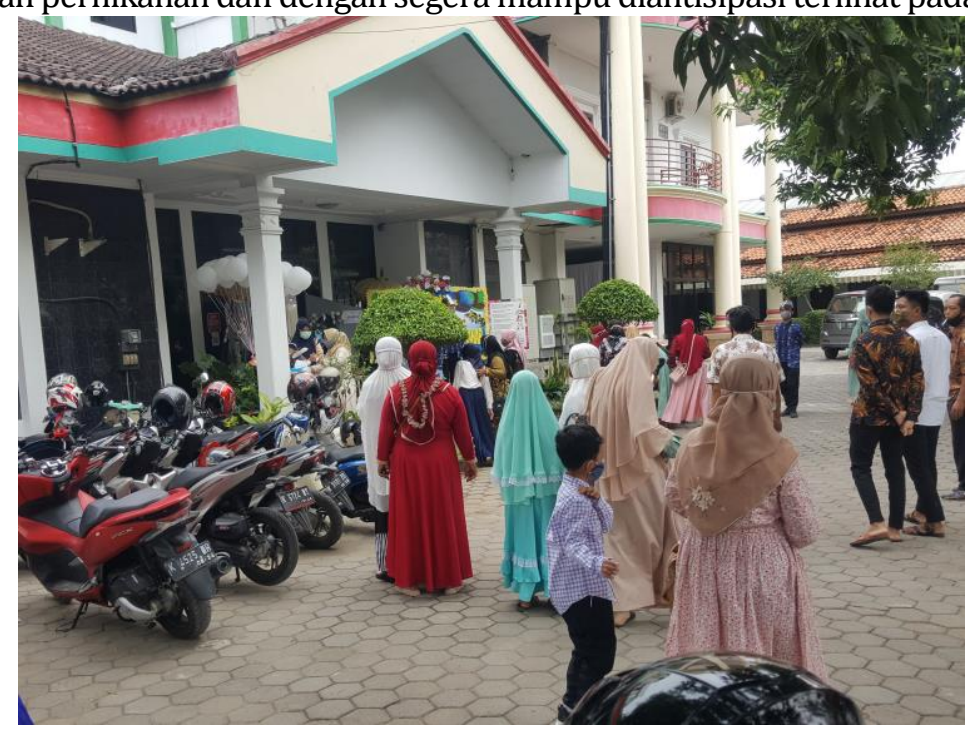

\section{Gambar 2 Potensi kerumunan yang terjadi}

Potensi permasalahan lain yang terjadi mengenai pengurangan jam kerja di masa pandemic memungkinka pekerja untuk bekerja di lain profesi utama yang digeluti dengan ijin pimpinan.

Penurunan kunjungan terasa sekali terjadi di awal masa pandemi seperti yang disampaikan oleh Eddy. Minimnya informasi mengenai apa yang boleh dan tidak menjadi salah satu alasan penurunan yang terjadi. Lambat laun, kunjungan tamu mengalami peningkatanterutama pada bagian barang yang banyak melakukan perjalanan dan menginap serta melewati jalur pantai utara jawa serta adanya adanya beberapa libur nasional pada oktober dan desember tahun 2020.

Elly salah seorang karyawan yang cukup berpengalaman dalam berinteraksi dengan tamu, menyebutkan bahwa masa pandemi kali ini cukup memukul jumlah tamu yang berkunjung. Diperkuat dengan data tamu yang semakin menurun di masa pandemi kedua tahun 2021 mulai dari bulan April hingga Juni akibat adanya pembatasan secara ketat dari regulasi pemerintah.

Tabel 4 Kunjungan pada bulan Januari-April

\begin{tabular}{lll}
\hline No & Bulan & Jumlah Tamu \\
\hline 1 & Januari & 331 \\
\hline 2 & Februari & 219 \\
\hline 3 & Maret & 299 \\
\hline 4 & April & $288 /$ \\
\hline
\end{tabular}


Industri perhotelan mengadaptasi tatanan kehidupan baru ini dengan lebih fleksibel. Fleksibilitas dapat diterapkan dengan mengurangi kontak langsung dalam kegiatan fisik seperti surat menyurat (Clark, 2020). Fleksibilitas menjadi suatu kunci dalam tetap mengurangi penyebaran covid-19.

Beberapa tatanan kehidupan baru yang dapat diterapkan pada industry perhotelan antara lain (PHRI, 2020):

a) Memeriksa suhu tubuh karyawan yang diatas 37,3 derajat Celcius.

b) Penerapan gaya hidup bersih karyawan dengan rajin mencuci tangan sebelum, selama dan sesudah bekerja.

c) Penggunaan masker saat akan menuju lokasi hotel, dan mengganti masker saat akan memulai bekerja di hotel.

d) Penyediaan hand sanitizer pada lokasi yang dianggap perlu oleh pihak hotel.

e) Menghindari kerumunan

f) Mengurangi kontak fisik dalam melakukan registrasi tamu

Penerapan protocol baru tersebut di dalam hotel, diperlukan suatu kebiasaan dalam jangka waktu tertentu.

Pada Hotel Graha Dewata, penerapan protokol kesehatan masih bersifat fleksibel disesuaikan dengan kondisi dan situasi. Arya pengelola hotel Graha Dewata mengungkapkan penerapan protokol akan semakin ketat bila menghadapi kerumunan seperti adanya acara pernikahan atau rombongan tentu dengan arahan dari pihak terkait sebelumnya.

Kunjungan tamu terutama pada pengiriman barang sangat tergantung dengan regulasi pemerintah, sehingga saat pemerintah melakukan pembatasan secara ketat di beberapa wilayah, maka kunjungan tamu ikut mengalami penurunan yang terjadi pada akhir desember 2020 hingga awal januari 2021

\section{E. Simpulan}

Pelaksanaan protokol kesehatan pada Hotel Graha Dewata telah dilaksanakan sesuai dengan kemampuan yang dimiliki meskipun konsistensi belum dapat terjaga secara rutin. Kunjungan tamu mengalami kunjungan secara signifikan pada juni hingga desember 2020 tetapi tetap mampu menjaga kunjungan dengan adanya tamu dari pengiriman barang dari berbagai daerah dengan tetap melaksanakan protokol kesehatan yang telah ditetapkan oleh pemerintah. Setelah adanya pembatasan yang lebih ketat dari pemerintahan mulai januari 2021, terjadi penurunan tamu meskipun adanya banyak libur panjang.

\section{Ucapan Terima Kasih}

Penulis ucapkan terima kasih kepada Manajemen Hotel Graha Dewata atas bantuan dalam penggalian informasi di serta dukungan terhadap data yang diberikan.

\section{Daftar Referensi}

Advisory, F. I. P. H. (2020). CORONAVIRUS SARS-CoV-2 / COVID-19 PANDEMIC : Information and interim guidelines for pharmacists and the pharmacy workforce Coronavirus SARS-CoV-2 / COVID-19 pandemic : (March), 0-48.

Ateljevic, I. (2020). Transforming the (tourism) world for good and (re)generating the potential 'new normal'. Tourism Geographies. https://doi.org/10.1080/14616688.2020.1759134

Bard, T. R. (2020). COVID-19 and a New Normal? The Journal of Pastoral Care \& Counseling : JPCC. https://doi.org/10.1177/1542305020926831

130 Masyarakat Pariwisata: Journal of Community Services in Tourism, Volume 2 Nomor 2, 2021: 123-132 
Claessens, S., Djankov, S., \& Lang, L. H. P. (2000). The separation of ownership and control in East Asian Corporations. Journal of Financial Economics. https://doi.org/10.1016/s0304$405 x(00) 00067-2$

Clark, K. (2020). Innovation in a post-Covid 'new normal'. The Veterinary Record. https://doi.org/10.1136/vr.m1938

Coleman, S., \& Carsky, M. (1999). Sources of capital for small family-owned businesses: Evidence from the national survey of small business finances. Family Business Review. https://doi.org/10.1111/j.1741-6248.1999.00073.x

Darmawan, B. (2019). Intergenerational differences of family firms in Indonesia: financial structure and performance. Benefit Jurnal Manajemen Dan Bisnis.

Fajri, D. D. (2020). Pelatihan Penerapan Protokol KesehatanKaryawan Hotel di MasaTatanan Normal Baru. Abdimas Pariwisata, 1(1), 26-32.

Galve-Górriz, C., \& Salas-Fumás, V. (2011). Growth Strategies, Professionalization, Ownership Structure and Performance across Generations of a Family Firm. African Journal of Business Management. https://doi.org/10.5897/AJBM10.1649

Greenhaus, J. H., \& Powell, G. N. (2006). When work and family are allies: A theory of work-family enrichment. Academy of Management Review. https://doi.org/10.2307/20159186

Hoefer, A., Pampaka, D., Rivas Wagner, E., Alemán Herrera, A., García-Ramos Alonso, E., LópezPerea, N., ... Núñez Gallo, D. (2020). Management of a COVID-19 outbreak in a hotel in Tenerife, Spain. International Journal of Infectious Diseases. https://doi.org/10.1016/j.ijid.2020.05.047

Horwath, H. (2020). Survei Sentimen Pasar Hotel \& Restoran di Indonesia Terhadap Pengaruh Wabah COVID-19. In PHRI Online (Vol. 1). https://doi.org/10.32487/jst.v1i1.20

Kumar, V. (2020). Indian Tourism Industry and COVID-19: Present Scenario. Journal of Tourism and Hospitality Education. https://doi.org/10.3126/jthe.v10i0.28768

López-Delgado, P., \& Diéguez-Soto, J. (2015). Lone founders, types of private family businesses and firm performance. Journal of Family Business Strategy. https://doi.org/10.1016/j.jfbs.2014.11.001

Lumanauw, N. (2020). EDUKASI DAN IMPLEMENTASI PROTOKOL CLEAN HEALTH SAFETY ENVIRONTMENT MELALUI WE LOVE BALI KEMENPAREKFRAF PADA PROGRAM 10 SANUR - NUSA PENIDA - NUSA LEMBONGAN - SANUR. Jurnal Ilmiah Hospitality Management. https://doi.org/10.22334/jihm.v11i1.179

Molly, V., Laveren, E., \& Deloof, M. (2010). Family business succession and its impact on financial structure and performance. Family Business Review. https://doi.org/10.1177/0894486510365062

PHRI, B. P. P. (2020). PANDUAN UMUM NORMAL BARU HOTEL DAN RESTORAN.

Ranasinghe, R., Damunupola, A., Wijesundara, S., Karunarathna, C., Nawarathna, D., Gamage, S., ... Idroos, A. A. (2020). Tourism after Corona: Impacts of Covid 19 Pandemic and Way Forward for Tourism, Hotel and Mice Industry in Sri Lanka. SSRN Electronic Journal. https://doi.org/10.2139/ssrn.3587170

Ruan, W., \& Tian, G. (2011). Managerial Ownership , Capital Structure and Firm Value : Evidence from China' s Civilian-run Firms Managerial Ownership, Capital Structure and Firm Value : Evidence from. 5(3), 73-92.

Saadat, S., Rawtani, D., \& Hussain, C. M. (2020). Environmental perspective of COVID-19. Science of the Total Environment. https://doi.org/10.1016/j.scitotenv.2020.138870

UNWTO. (2020). TOURISM AND COVID-19. (March).

Villalonga, B., \& Amit, R. (2006). How do family ownership, control and management affect firm value? Journal of Financial Economics. https://doi.org/10.1016/j.jfineco.2004.12.005

World Health Organization. (2020). Coronavirus Disease Situation Report World Health World Health Organization Organization (Vol. 19).

Yuliana. (2020). Wellness and healthy magazine. 2(February), 187-192. 
Zeegen, E. N., Yates, A. J., \& Jevsevar, D. S. (2020). After the COVID-19 Pandemic: Returning to Normalcy or Returning to a New Normal? Journal of Arthroplasty. https://doi.org/10.1016/j.arth.2020.04.040 